UDC 75.044:725(497.113 Novi Sad)

https://doi.org/10.18485/ms_zmslu.2021.49.9

Оригинални научни рад

Јована Д. Миловановић

\title{
СВЕЧАНА САЛА ГРАДСКЕ КУЋЕ У НОВОМ САДУ КАО ПРОСТОР ВЛАДАРСКЕ РЕПРЕЗЕНТАЦИЈЕ: ОД ЦАРА ФРАњЕ ЈОСИФА І И ЦАРИЦЕ ЕЛИЗАБЕТЕ ДО КРАЉА АЛЕКСАНДРА И КРАЉИЦЕ МАРИЈЕ КАРАЂОРЂЕВИТ
}

\begin{abstract}
САЖЕТАК: Портрети владарских парова Аустроугарске монархије и Краљевине СХС који су били смештени у свечану салу новосадске Градске куће доживели су исту судбину - са нестанком државе на чијем челу су се налазили, нестале су и њихове слике из репрезентативног јавног простора. Пропаст Двојне монархије и постанак Краљевине СХС условили су смештање двојног владарског портрета у истии простор, чак и истие рамове, што је требало да отелотвори нова идеолошка стремљења, и да младу југословенску државу учини присутном у симболичкој политици на новоосвојеној територији. Уклањање, а затим постављање нових владарских ликова у простор јавне репрезентације сведочи о естетско-симболичкој димензији политике, чији ће сликовно-стратешки механизми бити испитани на примеру једне просторије, једног града, готово истоветне заједнице конзумената, али у две државе, са два различита владарска пара у њиховом средишту.

КљУЧНЕ РЕЧИ: владарска репрезентација, Градска кућа у Новом Саду, Аустроугарска монархија, Краљевина СХC, цар Фрања Јосиф I, царица Елизабета Аустријска, краљ Александар Карађорђевић, краљица Марија Карађорђевић.
\end{abstract}

Увод

Портрет цара Фрање Јосифа (Franz Joseph I) новосадске власти су поручиле 1892. године поводом обележавања четвртине века од његовог крунисања за апостолског краља Угарске у Будиму 1867. године; ауторство слике није докраја утврђено. Портрет његове супруге, царице Елизабете Аустријске (Elisabeth von Österreich-Ungarn), настаје 1899. године како би се обележила годишњица владаркине смрти у атентату

* Универзитет у Београду, Филозофски факултет, jovana.milovanovic892@gmail.com 


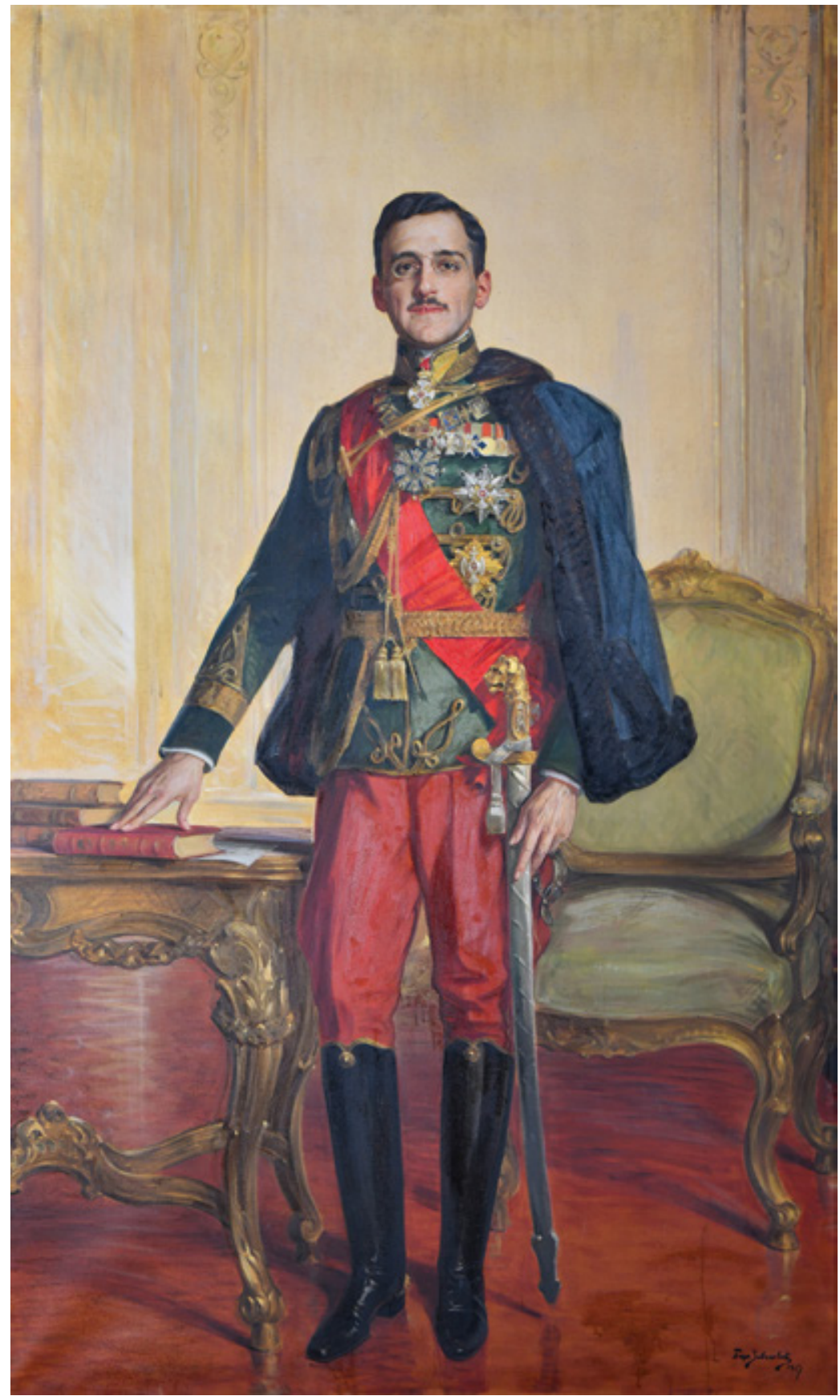

Сл. 1. Паја Јовановић, Крать Алексанgар Карађорђевић, уље на платну, 1927. (Галерија Матице српске) 


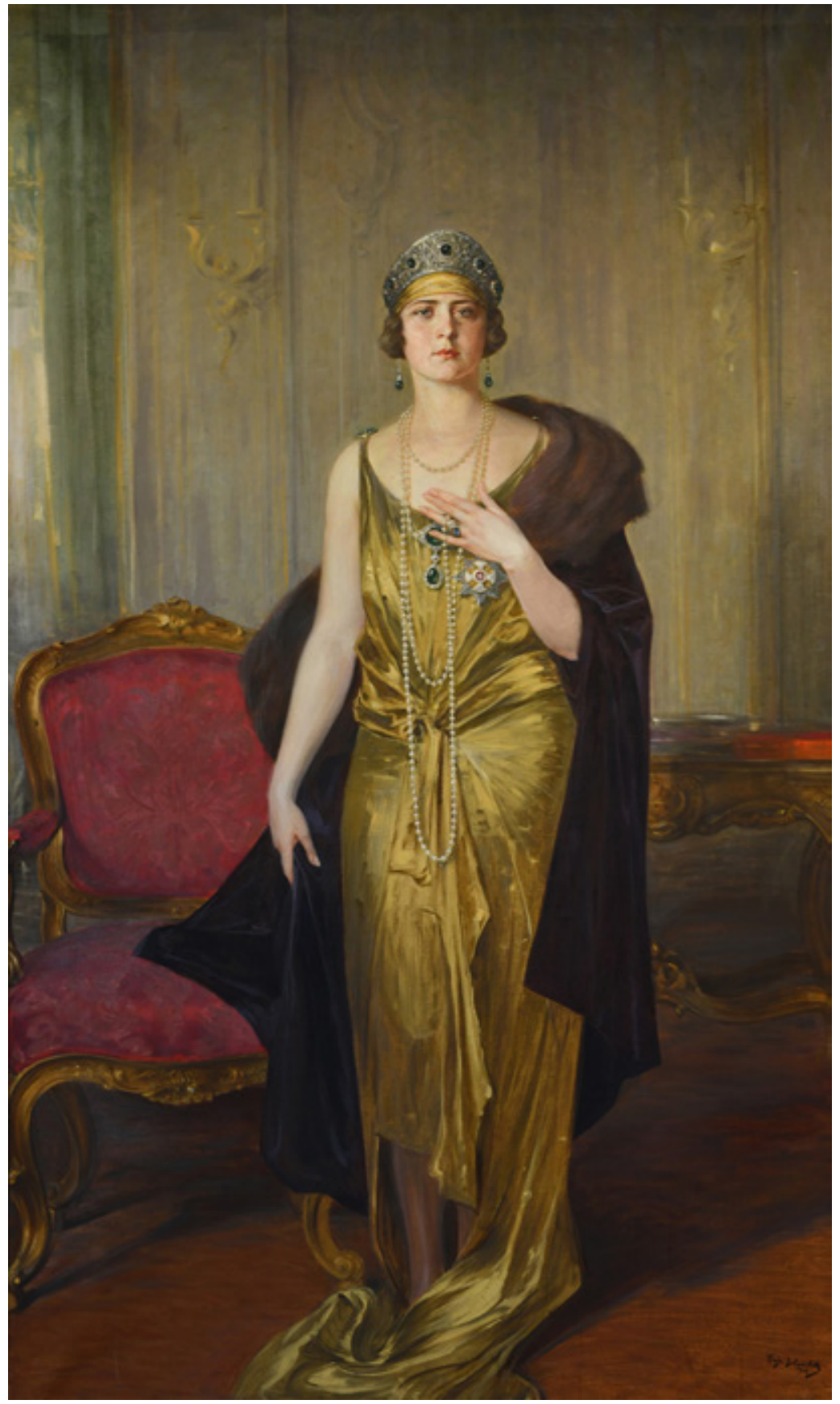

Сл. 2. Паја Јовановић, Кральиа Марија Карађорђевић, уље на платну, 1927. (Галерија Матице српске) 
у Женеви 1898. године; за овај посао је унајмљен прослављени мађарски сликар Ђерђ Ваштаг (Vastagh György), који је поред репрезентативне слике израдио и раскошни рам (ЛАзић 2016: 133). Крај Великог рата 1918. године окончао је постојање вишевековне Хабзбуршке монархије, а делови њене јужне територије постаће део новоформиране Краљевине Срба, Хрвата и Словенаца. Већ у првим месецима постојања државе Јужних Словена парадни портрети некадашњег владарског пара извађени су из рамова са бочних зидова свечане сале и похрањени у архиву Градске куће. Деценију касније у исте рамове биће постављени портрети краља Александра (сл. 1) и краљице Марије Карађорђевић (сл. 2) које је израдио вишеструко етаблирани сликар владарских портрета - Паја Јовановић. Репрезентативне слике Карађорђевића доживеће исту судбину као и оне чије су место заузеле - Други светски рат и још једна промена режима условиће уклањање дела са приказима Карађорђевића из јавног простора. За разлику од портрета Хабзбурговаца којима је сваки траг изгубљен, портрети Карађорђевића се чувају у Галерији Матице српске (Милошевић, ВрьАшки 2004: 21).

Владарска репрезентација путем сликовних медија током свог вишевековног постојања доживела је многобројне трансформације које су биле у складу са временом у ком је настала, као и са потребама које је требало испунити. Ипак, за све то време она је пласирана као политичка слика са намером да визуелизује одређени поредак; однос моћи и владарске слике био је у константној тензији, те је портретом исказиван или постојећи положај владара, или степен моћи који је требало достићи. Уклањање и(или) уништавање слика које еманирају одређени поредак, присутно од најстаријих цивилизација до данашњих дана, сведочи о њиховој архаичној снази. Чин познат као damnatio memoriae означава забрану сећаға, односно манипулисање колективном меморијом, а владарске слике као живући носиоци владарског присуства и легитимитета одређеног система владавине, када тај исти систем нестане, у основи губе право на постојање или барем на јавно присуство, као што је случај са ова четири портрета (FLECKNER 2011: 208-215).

Однос владарске слике као пластичне форме, намене коју је требало испунити и простора у који је била смештена указује на међусобну узрочност значења владарске слике и простора коме је намењена (БорОзАН 2013: 3-4). Истовремено, слика бива дефинисана својом позицијом у одређеном простору, али, захваљујући инверзном процесу, она такође дефинише простор. Владарски ликови хабзбуршког царског и краљевског пара у свечаној сали новосадског Магистрата требало је да означе присуство државе - Аустроугарске монархије, и то са мађарским националним подтекстом ако се у обзир узму детаљи. Читање владарске слике у различитим државнополитичким оквирима која је путем владарског лика требало симболички да укаже на владарску величајност, али и да успостави претпостављену комуникацију са примаоцима визуелне поруке, омогућио је метод политичке иконографије (FLECKNER, WARNKE и др. 2011).

Студије владарске репрезентације која је аргументована снагом визуелне представе која почива на различитим структурама теорије прикладности, раширена је међу истраживачима европских монархија. Исти приступ се примењује и на хабзбуршко- 
-лотариншку династију и концентрише се на настанак слике; на начине којима је одређени идеал отелотворен у визуелним медијима; репрезентација споменуте династије може се сагледати као процес креирања савршене слике њених чланова, идеалне перцепције моћи и извора утицаја, као и ауторитета. Стога се уметничко дело може разумети као конструкција, знак у значењском смислу или форма комуникације кроз симболе (YONAN 2017: 22-23). У другој половини XVIII века владарска слика се постепено трансформише, раније круте, наративне структуре постепено се разбијају и замењују динамичнијим композицијама. У XIX веку основни циљеви које је владарска репрезентација требало да испуни били су сажето, опште разумљиво и пропагандистички ефикасно величање главног јунака (TELESKO 2010: 57-65), што ће се наставити и у првим деценијама XX века. Различити визуелни медији нису само преузели репрезентативну или рефлективну функцију у процесима политичке комуникације, напротив, они не само да приказују већ и перформативно интервенишу својим специфичним визуелним потенцијалом, стварајући сопствену стварност одређеним порукама, односно постулатима адресата који ту поруку примају (TELESKO 2010: 65).

\section{Новосадска градска кућа као простор репрезентације у Аустроугарској}

Градски простор Петроварадинског Шанца имао је вишевековни континуитет насељености пре него што је званично добио повељу којом је проглашен слободним краљевским градом и добио ново име - Неойланйа (нем. Neusatz, мaђ). Újvidégh), које се међу српским становништвом одомаћило под називом Нови Cag. Царица Марија Терезија заслужна је за именовање града, као и за издавање повеље 1. фебруара 1748. године којом је град стекао многе олакшице, али и ново административно уређење - главно управно тело Магистрат (БЕшлин 2014: 74). У XVIII и XIX веку Нови Сад је заостајао за другим градовима у јужној Угарској, претрпевши велике губитке у рату 1848. године. До средине XIX века православно становништво, на челу са српским етничким корпусом, чинило је већину градског становништва, а са настанком Аустроугарске монархије претекло га је мађарско становништво - до почетка Првог светског рата у граду је живело 13.000 Мађара, 11.0оо Срба, 6ооо Немаца и 1700 „осталих” (БЕшлин 2014: 80). За све време заједничког живота под окриљем Хабзбуршке монархије долазило је до међунационалних размирица између Срба и Мађара што се огледало и у изградњи простора Градске куће; почевши од сукоба из 1848. године, успеха српског народа и неуспеха мађарског, преко историјског обрта укидањем српске аутономне јединице 1861. године и оснивањем Двојне монархије тек коју годину касније, међунационална нетрпељивост и борба за превласт у јавној сфери остаће присутне докраја постојања Монархије. У Угарској пре Првог светског рата Нови Сад није био центар са значајним потенцијалом за остварење мађарске националне симболичке географије, што не значи да је остао ускраћен за било какве покушаје; такође није био истакнут ни као нарочито проминентан градски центар јужних крајева државе, као што се то може рећи за Суботицу, Темишвар или Земун. С друге 
стране, у нову државу Нови Сад улази као „незванични центар Срба у Угарској”, уз популарни назив Српска Атина - снажан идеолошко-политички и културно-симболички потенцијал су га учинили „природним” средиштем Војводине, обликоване новим државним границама, што ће и званично постати успостављањем Дунавске бановине чији ће центар бити (РАдовић 2017: 218-219).

После једноиповековног сељења по граду и многих несугласица између опозиције и владајућих структура, новосадски Магистрат коначно добија своју зграду 1894. године на Главном градском тргу, насупрот римокатоличке Цркве Име Маријино (СТАнчИЋ, ЛАзОвИЋ 2015: 46-47). Изградња или доградња репрезентативних здања за смештање државних и градских институција била је једна од главних одлика читавог периода постојања Аустроугарске монархије, како у центрима - Бечу и Будимпешти, тако и на периферији - на простору јужне Угарске. Изградњу репрезентативних здања која су доминирала градским пејзажом пратило је постављање дела ликовне уметности, превасходно слика, портретног или историјског жанра, чија је основна намена била да искажу политички програм наручиоца или замишљене политичке циљеве које је требало остварити. ${ }^{1}$ Како на простору читаве Монархије, тако и у њеним јужним деловима, слике царског пара су биле свеприсутне у јавности, творећи јединствено визуелно искуство на културном простору Хабзбуршког царства (TELESKO 2008). ${ }^{2}$

Увид у специфичан однос између институција Хабзбуршке монархије и династичких слика пружа нам илустративан пример из 1779. године када је краљевски комесар и опуномоћеник Марије Терезије боравио у Великом Бечкереку како би увео у дужност нову жупанијску администрацију. Том приликом у центру града је био постављен велики шатор у ком су „са леве стране стајали новопечени жупанијски званичници - поджупан, главни бележник итд. - док је са десне стране изнад стола са повељом о рестаурацији Жупаније и жупанијским печатом висио портрет Марије Терезије" (Крчмар 2016: 36). Овај пример потврђује снагу поимања владарске слике као супститута самог владара - њено присуство дефинише простор државне институције пружајући му политички и симболички смисао, али и еманирајући владарску моћ оличену у тесној вези између личности, тела и дужности (БоРОЗАН 2012: 97).

${ }^{1}$ Широм Угарске краљевине, нарочито након 1867. године, простори магистрата и жупанијских средишта на територији јужне Угарске постају симболички центри званичне државне политике на периферији, која је долазила пре свега из угарског центра - Пеште, док је центар династичке моћи остао Беч. Нарочито сликовит пример јесте слика Дефиле банайских сйахија йреg иарем Фрағом Јосифом I, настала након Миленијумских свечаности у Угарској 1896. године, креирана као историјска композиција, али садржи и слику цара, као и репрезенте локалне власти (МиловАНОВиЋ 2016: 201-219).

2 У домаћој историографији у последње време све више се обраћа пажња на примере доступних репрезентативних портрета Хабзбурговаца намењених просторима јавне репрезентације, насталих на територији јужне Угарске (данас у саставу Републике Србије), попут оних из објеката Торонталске жупаније у данашњем Зрењанину (КрчмАР 2016; МиловАновит 2016), Бачко-бодрошке жупаније у Сомбору (МилОвАНОвИЋ 2020) и Градске куће у Суботици (КуцОР 2020), као и у јавној сфери српског етничког корпуса (БОРОЗАН 2012; 2014). 
Владарска слика и њена способност генерисања политичког легитимитета кроз емоционалну заједницу у другој половини XIX века доживљавају свој врхунац. У сложеном процесу национализације, монархије су током XIX века сукцесивно замењиване или допуњаване апстрактним прописима, телима и парламентима. У складу с тим се и монархијска владавина „национализује”, а владарска слика се уподобљава потребама које је требало да уједине монарха и грађане. Посебна етничка разноликост је природно ограничила могућности „национализације” личности владара Фрање Јосифа I на начин који је био оствариван у Немачком царству или Великој Британији (TELESKO 2010: 57-76). Ипак, од времена Аустро-угарске нагодбе 1867. године, када наступа дуалистичко уређење, царски портрети у угарском делу Монархије све више задобијају мађарски национални предзнак, пре свега путем одежде и других елемената репрезентације (БоРОзАн 2014: 141-170; МилОВАнОВИЋ 2020: 55-79), што ће бити случај и са портретима намењеним Градској кући у Новом Саду.

У другој половини XIX века долази до наглог развоја разноврсних медија визуелне културе, појава фотографије ће однети превагу, што ће као последицу имати могућност умножавања династичких портрета и њихово брже продирање у јавно мњење Монархије; ипак, потреба за креирањем репрезентативних портрета владарског пара није нестала. Од 1860. године, а нарочито у периоду након крунисања царског пара из Беча за краља и краљицу Угарске 1867, у свечане просторије државних и научних институција широм угарског дела Монархије постављају се владарски репрезентативни портрети. У погледу уметничког домета ови портрети нису нарочита остварења. Међутим, они су допринели порасту сликарске продукције у Угарској, будући да су пре друге половине XIX века овде ретко рађени репрезентативни портрети великог формата (SZVOBODA DOMÁNSZKY 2018: 567-569).

Галерије портрета у јавном простору институција на периферији Мађарске играле су важну улогу у визуелизацији и креирању мађарске националне идеје. У новијим истраживањима термин Gelegenheitbilder ${ }^{3}$ пледира на ову врсту сликарске продукциje, а превасходно се односи на слике, у које се убраја и портретни жанр, које су настајале специјалним поводом у XIX веку. Мађарска историчарка Ева Бичкеи (Bicskei Éva) овај израз је употребила као парадигму која означава слике намењене смештању у јавни простор градских кућа, жупанија и осталих институција, сагледавајући их као засебан жанр, који је у историји уметности био занемариван дуго времена, а чија је улога у политичком животу била веома важна (BICSKEI 2008) будући да су својим присуством, макар и уз недостатак уметничких квалитета, ипак утицале на креирање симболичке стварности.

Делујући у складу са културном доктрином национализма, артефакти визуелне културе били су активни сакреатори мађарске нације у другој половини XIX века

3 Термин Gelegenheitbilder jе сковао уметник и уметнички критичар Густав Келети (Kelety Gusztáv), а први пут га је употребио да би описао слику Ђуле Бенцура Осниване йрвої мађарскої осиїуравајућеї gрушй $в а$ из 1883. године. У свом изворном значењу, употребљеном 1910. године, односио се на слике настајале по наруџбини, са способношћу да „неинтересантне субјекте уздигну до нивоа праве историјске слике”. 
(SмIT 2010: 115-127). Сложена ситуација у Аустроугарској монархији истовремено је изискивала и династичку лојалност монарху, која је поистовећивана са лојалношћу држави, односно наднационалним патриотизмом који се очекивао од сваког поданика Монархије. Паралелни симболички процес који је текао међу припадницима мађарског народа, у свом средишту је имао круну Св. Стефана, а владар из дома Хабзбурга је посматран као носилац свете мађарске круне, у којој је сумирана доктрина угарске државности. Портрети су били визуелни исказ политичких ставова локалне заједнице, омогућавајући истовремено да људи са периферије учествују у формирању модерног мађарског националног идентитета. Галерије портрета у жупанијама широм Угарске срећу се од XVIII века, након што је ово подручје пало у руке монарха из дома Хабзбурга. Када се обрати пажња на тип личности чији су портрети постављани у просторе средишта локалних власти, без изузетка се може рећи да су најзаступљеније биле представе оних који су у рукама имали апсолутну политичку моћ портрети краљева и чланова владарске породице. Друга по бројности група представљених личности су били локални моћници, попут жупана и градоначелника, а било је слика и истакнутих мађарских политичара (BICSKEI 2008: 308), што ће бити случај и са Градском кућом у Новом Саду.

Тридесетих година XX века велика афера, предмет новинских натписа не само у Новом Саду већ уопште, био је нестанак портрета царице Елизабете и цара Фрање Јосифа са тавана Градске куће у Новом Саду. ${ }^{4}$ Ови текстови у новинама доносе информације о некадашњем изгледу свечане сале у Градској кући у Новом Саду која је, попут осталих репрезентативних простора у Угарској, била организована као пантеон мађарске нације и аустроугарске државе. У београдском Времену 16. октобра 1936. године излази чланак под насловом „Новосадска општина објашњава загонетни нестанак слике царице Јелисавете са тавана градске куће”, а из једног одломка дознаје се:

Слике Фрање Јосифа и царице Јелисавете које су за време аустроугарског режима са сликама других великодостојника биле изложене у градској већници, скинуте су и уклоњене из већнице још 1918. године, одмах по ослобођењу. Доцније, скупоцени рамови ових слика Фрање и Јелисавете употребљени су 1928, за слике Блаженопочившег Витешког Краља Александра І ујединитеља и Њ. В. Краљице Марије, које је за Општину израдио познати академски сликар г. Паја Јовановић. Слике Фрање и Јелисавете пак остављене су на тавану градске куће. Истрага је утврдила да слике цара Фрање и царице Јелисавете, а ни слике осталих великодостојника - међу којима је било и од велике

4 Љиљана Лазић, музејска саветница Музеја града Новог Сада, у свом раду „Афера нестанка портрета царице Јелисавете из Градске куће у Новом Саду у светлу новинских извештаја 1936-1938. године” подробно је обрадила питање нестанка портрета царице Елизабете, износећи притом многе корисне детаље који су послужили нашем истраживању (ЛАзић 2016: 133-148). 
уметничке вредности, чак и много веће вредности од слика Фрање и Јелисавете - још од 1918. године па све до данас нису вођене у инвентару имовине Општине града Новог Сада (Аноним 1936: 9).

Године 1892. широм Угарске је обележавана двадесетпета годишњица крунисања Фрање Јосифа за апостолског краља Угарске, што је био повод за поручивање владарских портрета многих јавних установа на периферији државе. Како би обележиле овај јубилеј, новосадске власти су наручиле краљев портрет, који је првобитно био изложен у Жандармеријској касарни (на месту данашње Робне куће „Базар”), будући да нови објекат Магистрата на тадашњем Тргу Фрање Јосифа још увек није био довршен. Ауторство слике се не спомиње ни у новинским текстовима ни у публикацијама које су већ помињале овај портрет; спорадично је наведено неколико информација, од којих је релевантна да је портрет рађен по фотографији, што не чуди с обзиром на распрострањеност слика са ликом Фрање Јосифа чија је продукција додатно расла када су у питању били јубилеји поПут овог (БОРОЗАН 2014; ЛАЗИЋ 2016).

За разлику од портрета Фрање Јосифа о

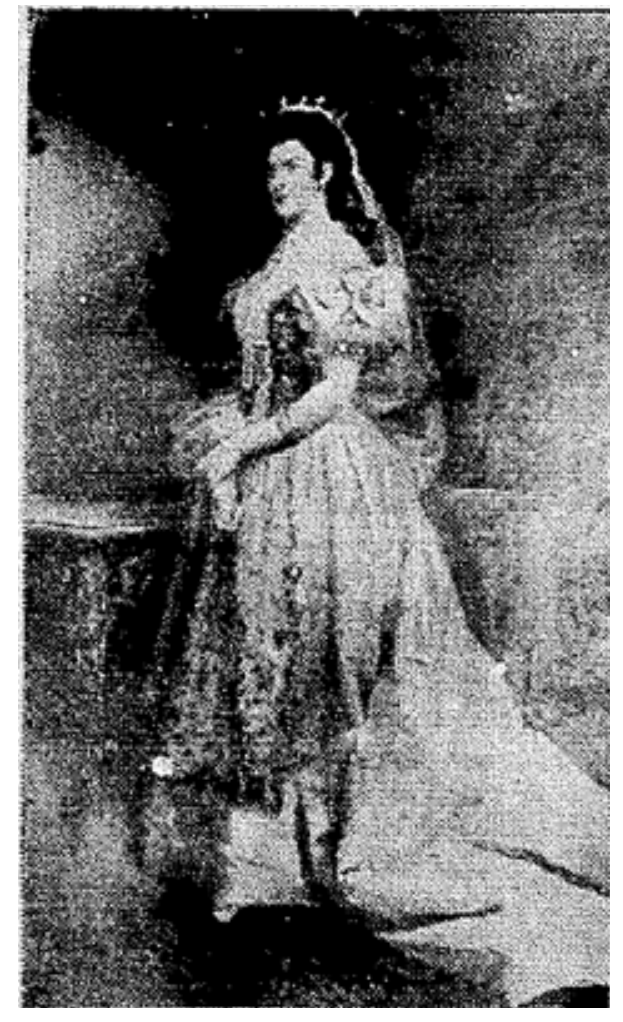

Сл. 3. Ђерђ Ваштаг, Царииза Елизабетиа Аустиријска, уље на платну, 1899.

(Политика, 29. октобар 1936) коме су информације прилично оскудне, о портрету владарке постоји много више података. Наиме, портрет је поручен и израђен 1899. године, када се навршавало годину дана од страдања царице Елизабете у атентату у Женеви. За овај посао је ангажован етаблирани сликар Ђерђ Ваштаг, а истом приликом му је затражена и израда украсног рама, који ће након 1918. примити портрете Карађорђевића.

Будући да је краљичин портрет изгубљен, његов изглед нам је данас познат искључиво на основу репродукције из Полийике од 29. октобра 1936. када је полемика била у јеку (сл. 3). Међутим, ранија истраживања помогла су у расветљавању уметничких одлика овог дела. У последњој четвртини XIX века настају многобројни портрети хабзбуршке царице, а Ђерђ Ваштаг је насликао неколицину њих. Типска појавност царице Елизабете као мађарске краљице била је честа тема Ваштагових слика; у периоду када је радио на слици намењеној простору Магистрата у Новом Саду, настају још два портрета која су нам данас позната. У питању су дела из градских већница словачког града Банска Штјавњица (некада угарског града Selmecbánya) и мађарског 


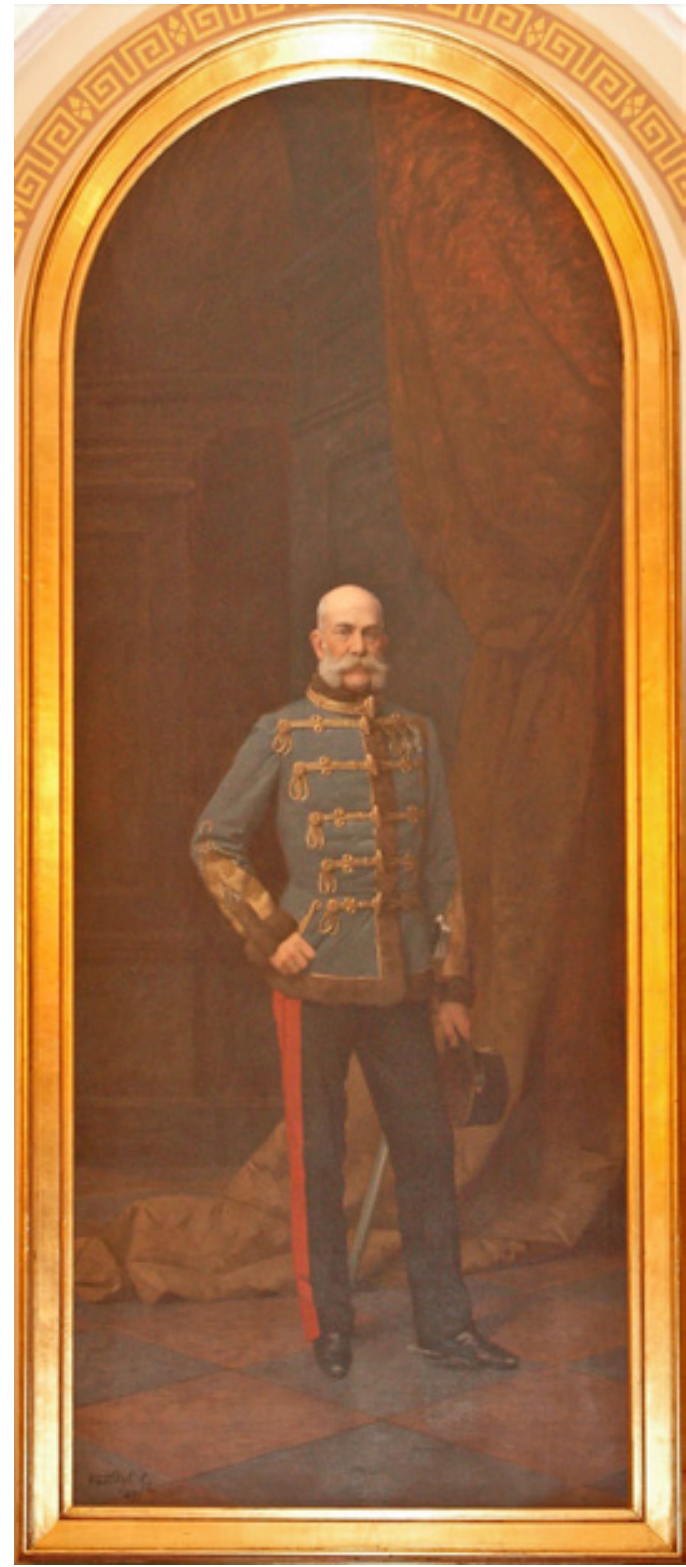

Сл. 4. Ђерђ Ваштаг, Цар Франа Јосиф I, уље на платну, 1899. (Градска кућа Ходмезевашархељ) (фото: Силвестер Алфаши (Alfási Szilveszter))

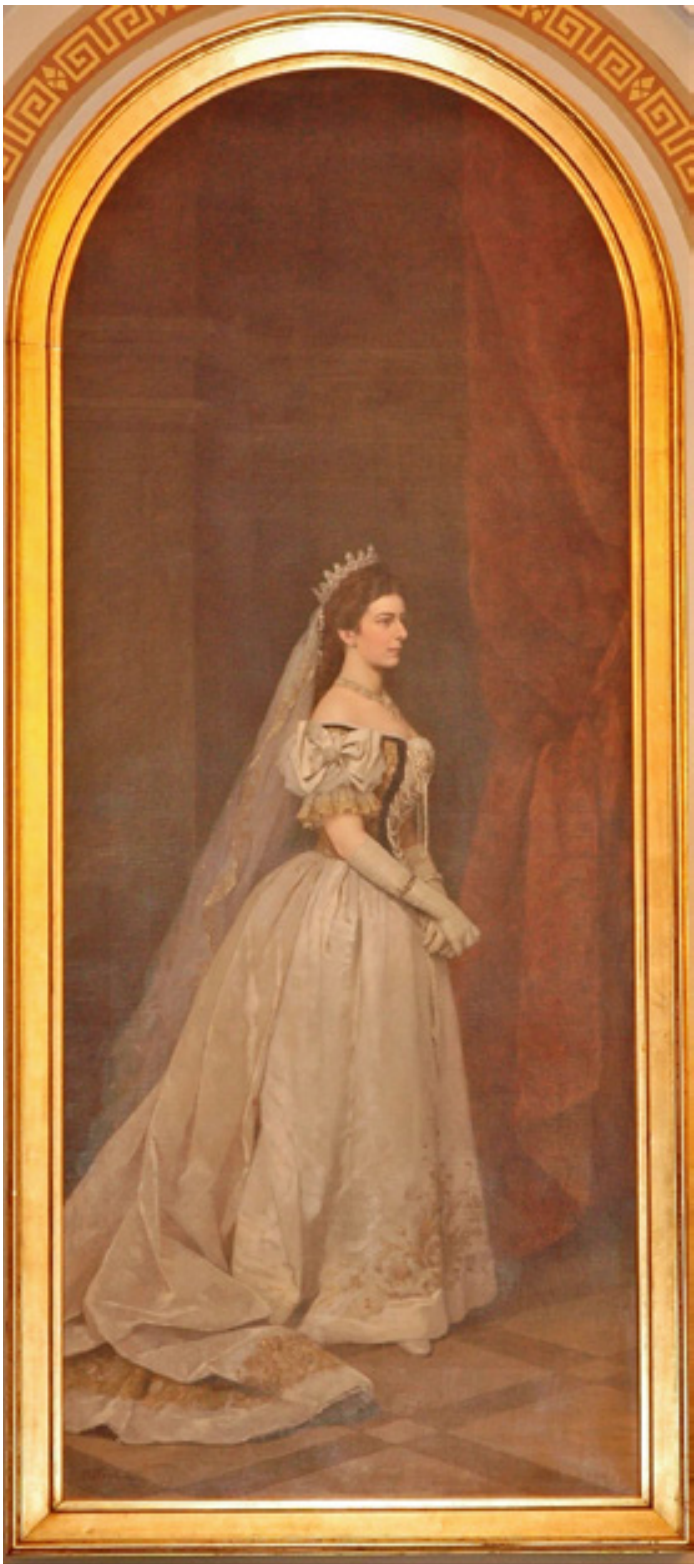

Сл. 5. Ђерђ Ваштаг, Царииа Елизабетиа Аустиријска, уље на платну, 1899. (Градска кућа Ходмезевашархељ) (фото: Силвестер Алфаши (Alfási Szilveszter)) 
града Ходмезевашархељ (Hódmezővásárhely) (сл. 4, сл. 5). Портрет из Банске Штјавњице је донет у тај град 1925. године, а од 1899. до 1925. се налазио у Градској кући словачког града Шахи (Šahy, некада угарски град Ipolyság) (ЛАзић 2016).

И новосадска слика, као и друге две поменуте Ваштагове слике са приказом краљице Елизабете, у потпуности се ослања на фото-серију бечког фотографа Емила Рабендинга (Emil Rabending), насталу 1866. године. Ове фотографије утрле су пут представљању владарке као 'мађарске националне хероине' - употреба симболичке политике и креирање култа владарке путем владарске репрезентације била је директно управљена на побољшање односа између бечког двора и мађарског народа. Производња слика царице из дома Хабзбурга у хаљини која је представљала мађарску националну ношњу уочи потписивања Нагодбе, са могућношћу велике дистрибуције, имала је јасну намену у обликовању мађарског јавног мњења. Пажљиво инсцениране фотографије требало је да истакну осећања „подршке” и „љубави” према Мађарима која су долазила од владарке, али и да делују на обострано задовољство бечког двора и угарских политичких првака (МиловАновић 2020).

Неозабилазни симболички означитељ свих слика са ликом краљице Елизабете, према којој је у Угарској гајена посебна наклоност, била је хаљина коју је она носила током свечаности крунисања у угарској престоници 8. јуна 1867. године. Њена владарска слика остаће упамћена по овом одевном комаду који је обележио Елизабетино владарско тело, а изведена је по узору на мађарску свечану одежду - gucмађар, коју је креирао чувени париски кројач Чарлс Фредерик Ворт који је израђивао хаљине за многе владарке и припаднице аристократије широм Европе. Хаљину одликује комбинација беле и црне боје, корсет је обликован у потпуности према guсмађар костиму, употребом преплета бисера и чипке, док су рукавима доминирали карнери и машне. Доњи део хаљине је потпуно бео, са предње стране се спушта декорисана, чипкаста кецеља, такође важан елемент мађарског националног костима (SIDó 2014: 207-215). Доњи део хаљине се завршавао шлепом, чија је дужина била прописана (око 3,5 метара). На глави је имала дијамантску круну, декоративне природе, која није указивала на њено владарско достојанство, а из које се спуштао раскошан бели вео (VoGel 2006: 229-231). У основи тумачења владарских портрета лежи теорија Ернста Канторовица (Ernst Kantorowitz) о два владарева тела која се темељи на

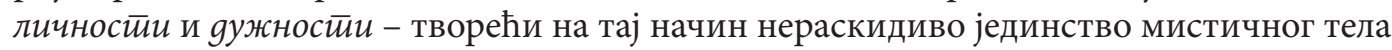
од пропадљивог - смртног тела и непропадљивог - вечног тела оличеног у монархији (БоРОзАн 2013). Када је реч о владаркином телу, ситуација је сложенија - за разлику од легитимних владарки попут британске краљице Викторије, владарке попут царице Елизабете Аустријске и краљице Марије Карађорђевић су у највећој мери саображене улогама својих супруга, те се и њихов легитимитет превасходно заснивао на улози владареве супруге, односно мајке престолонаследника. Осим тога, поред два владарева тела по Канторовицу, смртног и бесмртног, владарке у оквиру своје личности добијају још једно, треће тело, а то је женско иелло. Улога владарке у ХІХ и у првим деценијама XX века је у највећој мери дефинисана у строгим оквирима 
патријархалног брака, где се од жене очекују послушност, фамилијарност и честитост, као основни елементи женствености. У складу с тим се и слика владарке уподобљава очекивањима њених конзумената, те се од ње очекује да је аполитична. Међутим, на примерима слика које су у нашем фокусу видећемо да ни тело владарке није заобишло учитавање различитих идеологија.

Слика аустријске царице Елизабете као мађарске краљице на простору угарског дела Монархије била је предмет политизације током читавог периода постојања дуалистичке уније, а чак и пре, одмах након удаје баварске принцезе за младог цара Фрању Јосифа. Култ царице Елизабете као мађарске хероине темељио се на разноврсним чињеницама кроз које се огледала њена приврженост мађарском народу - познавање мађарског језика, утицај њене дворске даме, Мађарице Иде Ференци (Ferenczy Ida), романтизовано поистовећивање царичине слободољубиве природе са слободољубљем мађарског народа итд. Ово је био двосмерни процес кроз који су угарски политичари настојали да „мађаризују” припадницу династије Хабзбург, што је истовремено одговарало и двору у Бечу, како би константне тензије са Мађарима макар на нивоу симболичке политике биле ублажене. Једно од речитијих средстава у политизацији не само владарског тела већ уопште било које личности у XIX веку, у доба процвата национализма, било је ношиво у које се одређена особа заодева (МАкуљЕвић 2006: 135-137). На примеру царице Елизабете је показано како је захваљујући пажљиво осмишљеној хаљини њеном владарском достојанству придружена титула мађарске краљице. Током свог живота, а нарочито после смрти, Елизабета у угарском делу Монархије није сагледавана искључиво као припадница владарског дома већ као истинска национална хероина (МиловАновић 2020: 69-76).

Упркос залагању колегинице Лазић није докраја утврђено на који начин су нестале слике владарског пара Фрање Јосифа I и краљице Елизабете из новосадског Магистрата. На основу записника са седница одбора за набавку слика краља Александра и краљице Марије, из фебруара 1926. године, сазнаје се да је једногласно прихваћен предлог „да се прода слика Фрање Јосифа и његове супруге”, а да се планирана сума од 60.000 динара употреби за набавку слика новог владарског пара. Поред тога што нам овај податак сугерише да су се почетком 1926. године слике Хабзбурговаца још увек налазиле у просторијама Градске куће (иако нису биле изложене), још важнија је „примена” устаљених пракси концепта damnatio memoriae. У доба антике неретко се дешавало да се на уклоњеној портретној статуи цара промени глава или, што је био чешћи случај, да се портретне црте представљеног појединца подвргну трансформацији која је за циљ имала изобличавање лика новог владара. У овим редизајнима фокус није био на уштеди материјала и времена у изради нових царских портрета, већ је статуа „проклетог” цара третирана као плен, чије је физичко уграђивање имало симболичну вредност (FLECKNER 2011). Ако у овим кодовима сагледамо потребу Савета града Новог Сада да средства за слике нових владара обезбеди 
продајом слика свргнуте династије, увиђамо да су репрезентативне представе Хабзбурговаца сведене искључиво на материјалну вредност коју је требало искористити не за тек коју намену, већ за креирање слика које ће заузети њихово место у постојећим рамским оквирима свечане сале новосадске Градске куће.

\section{Новосадска Градска кућа као простор репрезентације у Краљевини Срба, Хрвата и Словенаца}

Након Првог светског рата са историјске позорнице ће нестати Аустроугарско царство, а на територији на којој се некада простирало појавиће се неколико нових држава, међу којима је значајан простор заузимала држава Јужних Словена. Још за време ратних дејстава у Новом Саду биће формирани Народни савет као представничко тело, и Народна управа за Банат, Бачку и Барању, као извршно тело, чиме ће на неки начин бити наговештено да је Нови Сад у новој држави требало да преузме улогу административно-политичког центра у Војводини, иако тај термин тада још увек званично не постоји. Новом Саду је без сумње припала ова улога с обзиром на српску традицију коју је град баштинио у претходним временима, а уз повољан географски положај и привредну развијеност, поседовао је све предуслове да постане средиште из којег ће се вршити „национализација северних крајева” (БЕшлин 2014: 84). Мултинационално становништво на југу Краљевине Угарске сада је постало део Краљевине СХC, а механизми остварења национално-идеолошке кохезије овог простора вршени су на различите начине. На примеру Новог Сада јасно се може испратити симболичка трансформација из „аустроугарског” у „југословенски” град преко именовања градских улица и тргова по одређеним особама, топонимима и појмовима. Приликом именовања улица и тргова, и уопште јавних градских простора, често долази до две комплементарне симболичке праксе: комеморације - именовања одређеног простора по неком појму или особи, и gекомеморације - укидања, односно брисања појединих назива улица, тргова итд. (РАдовић 2017: 203). Декомеморација јавног простора често се спроводи као својеврсни „ритуал револуције” са извесним прокламацијским ефектом промене одређених назива којим се обзнањује значајна политичка промена. Истовремено, називи улица и тргова доприносе формирању жељене политичке свести међу популацијом (AZARYAHU 1986: 581).

Као што је већ био случај са национализацијом Новог Сада у складу са мађарском националном идејом, уз неизоставне одониме по члановима династије Хабзбург, у новој држави долази до брисања назива који су реферирали на претходне државне структуре, а нова комеморација обухватала је чланове владајуће породице Карађорђевића, као и личности из српске политичке и културне историје. Тако Трг

5 С. Радовић у свом раду „Идентитети и памћење у јавном простору: одономастика Новог Сада од аустро-угарског до југословенског града" опсежно се бавио именовањем и преименовањем улица у Новом Саду, чему ми нећемо детаљно посвећивати пажњу, већ ћемо се у складу са темом осврнути на кључне премисе. 


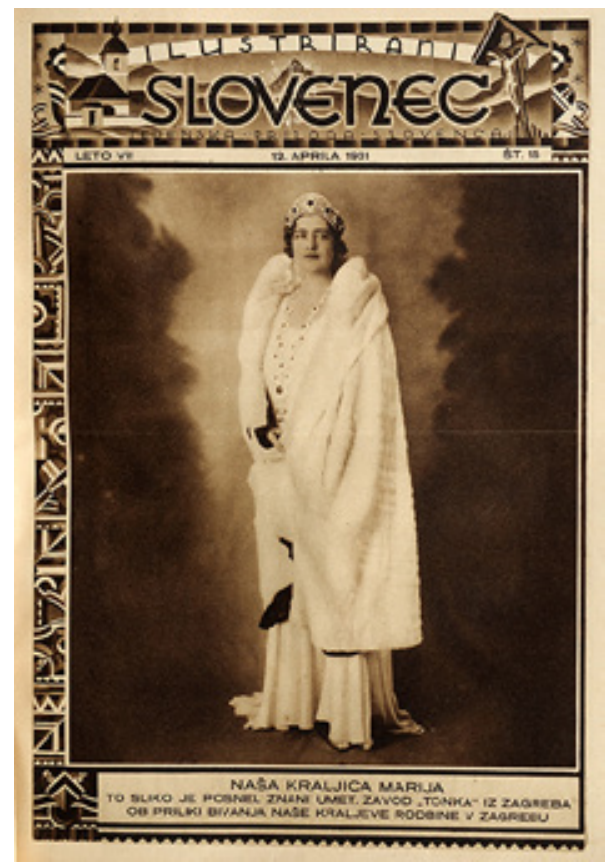

Сл. 6. Фото Тонка, Краљииза Марија

Карађорђевић, фотографија, 1931.

(Илуситрирани Словенеи, 12. април 1931)
Фрање Јосифа на ком се налазила Градска кућа сада добија назив Трг ослобођења, а из урбане номенклатуре нестаје и назив трга назван по краљици Елизабети - Јелисаветин трг (РАдовић 2017: 216-217). Стога, слике у свечаној сали Магистрата нису биле изоловани случај, већ су пратиле устаљену матрицу која је следила смене режима на одређеном простору. На који начин је виђена улога владарског портрета у новоприпојеним крајевима Краљевине СХC, сликовито сведочи одломак из писма сликара Васе Ешкићевића упућеног Градском савету Новог Сада октобра 1925. године: „По савету једног од г. Сенатора, ја сам још пре две год. поднео свој предлог - понуду Градском Савету ради израде великог портрета Њ. В. Краља за велику Градску салу, коју још и gанас, йосле шестиоїоgишњеі ујеgиюень украшавају - gве мале обичне и хрђаве рейрояукиије [курзив Ј. М.], које престављају Њ. В. Краља Александра, и блажено почившег Краља Ослободиоца Петра Великог, - онда када су до сада већ сви велики градови у Војводини, као што су: Суботица, Сомбор, Вел. Бечкерек, Вел. Кикинда и

Панчево - украсили своје Градске сале са великим уметничким портретима Њ. В. Краља." Он том приликом нуди Градском савету да изради велике портрете краља и краљице за велику Градску дворану. ${ }^{6}$ Годину дана пре тога један представник локалних власти на периферији Краљевине - жупан града Суботице, скреће пажњу на портрет краља Александра Карађорђевића, у „природној величини до колена”, који је израдио Паја Јовановић 1919. године, а који се налазио у његовој канцеларији све до почетка Другог светског рата (KOVAČEV NINKOV 2013: 180). Овај случај илустративно говори о значају владарске иконичне представе у званичној политици Краљевине СХС. Наиме, жупан је истакао да ово дело сматра једним од најбољих краљевих портрета, па предлаже да се оно званично механички умножи и дистрибуира за приватне и јавне потребе, чиме би се избегла неконтролисана масовна производња популарних патриотских икона са неодговарајућим краљевим ликом. Он им истовремено предлаже да се уведе званична цензура производње и употребе краљевог

${ }^{6}$ Градски савет није ни разматрао ангажман Ешкићевића за израду поменутих портрета, већ су контактирани првенствено Паја Јовановић а затим и Урош Предић, највероватније због високе цене коју је Јовановић потраживао. Предић је одбио да ради, док се Јовановић прихватио посла за накнаду од 120.000 динара, што је било дупло више од првобитно планиране. 
лика, за којим се у новоприпојеним крајевима, како истиче, јавља веома велика потреба (Тимотијевић 2009).

За разлику од портрета угарског краљевског пара који су данас једва познати, портрети Карађорђевића изложени су у водећој културној установи града Новог Сада - Галерији Матице српске. Одмах по избијању Другог светског рата, већ крајем априла 1941. године, заједно са још два портрета из свечане сале Градске куће, двојни владарски портрет Карађорђевића доспева у Музеј Матице српске (претеча данашње Галерије Матице српске) (ПАлковљевић БугАРски 2018: 25-26). Монументални репрезентативни приказ краља Александра I Карађорђевића Паја Јовановић је насликао 1927. године, сигнатура и година израде налазе се у доњем десном углу платна (сл. 1). Краљ је представљен у стојећем ставу, одевен у свечану униформу пуковника коњице Краљеве гарде, ${ }^{8}$ десном руком се ослања на књигу, а левом придржава раскошну сабљу са сопственим иницијалом. Краљ Александар носи о врату Орден Карађорђеве звезде са мачевима 3. степена и ланац Ордена Св. кнеза Лазара, преко десног рамена ленту Ордена Карађорђеве звезде са мачевима 1. степена, а остатак одликовања чине домаће и стране медаље и ордени (Петровић 2012: 167). ${ }^{9}$ Исте године Јовановић слика још један портрет краља Александра, у знак захвалности Матици српској за стипендију коју је користио као студент Ликовне академије у Бечу. Повод је био стогодишњи јубилеј ове институције. Готово истоветни приказ краља разликује једино краљевска порфира - плашт са крунисања његовог оца краља Петра I којим је огрнут, као и присуство владарских инсигнија круне и скиптра који су приказани на столу са десне стране (Петровић 2012: 168).

Иако је у питању типски приказ краља намењен новосадском Магистрату, вишеструко вариран, портрет одаје утисак владарског дигнитета и маскулинитета, као и одлучности захваљујући парадној униформи у коју је одевен, ${ }^{10}$ као и многобројним одликовањима намењеним истицању његових војничких врлина и заслуга. Ратни успеси које је актуелни краљ остварио присајединивши некадашњу угарску територију својој држави, садржани су у епитету Ујединитељ који је понео, на неки начин су визуелно сублимирани у његовом ношиву и одликовањима, као и мачу који

7 Слика је изведена техником уља на платну, њене димензије износе $150,5 \times 215 \mathrm{~cm}$, њен инвентарни број је ГМС/У 6, а дело је потписано и датирано у доњем десном углу: Паја Јовановић / 1927. Тре-

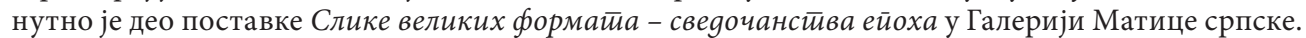

8 Униформу је идентификовао Ч. Васић у каталогу Службено оgело у Србији, сл. 88, 79, кат. 76.7. Униформа Краљеве гарде је измењена према Уреgби о униформама койнене војске из 1924. године, њом је уведена тамноплава миланка, слична кроју коњичке из 1882. године, за официре доламица тамноплава, уз јасно видљиве украсе и гајтане које уочавамо на краљевом портрету (ВАСИЋ 2001: 106).

9 Детаљније о одликовањима у П. Петровић.

10 И Ешкићевић у свом писму Градском савету наводи да би краља требало насликати у парадној гардијској униформи коју „Њ. В. Краљ нај радије носи”. 
нехајно придржава. Мач у левој руци подсећа на краља као предводника у рату, захваљујући ком је Нови Сад, као и остатак територије Војводине, постао део Краљевине СХC, док десна рука ослоњена на књигу - мотив који реферише на корпусе закона, често присутан у владарском портретном жанру, служи да подсети на то је владар истовремено предводник народа и у миру (Тимотијевић 2009: 199). Готово идентичан приказ краља уз незнатно измењену позадину из 1930. године, настао као поруџбина Трговачке банке из Вршца, сведочи о потреби за присуством лика новог владара на новоосвојеним територијама, што је наговештено у писму сликара Ешкићевића.

Паја Јовановић је и пре и после Великог рата сликао портрете припадника владарског дома Карађорђевића, али је паралелно радио и за царску породицу у Бечу, где је провео већи део свог живота. Током трајања рата, највероватније страхујући за свој положај у Бечу будући да је био српског порекла, Паја Јовановић израђује портрет цара Фрање Јосифа I који се данас чува у Народном музеју у Београду. ${ }^{11}$ Став аустроугарског владара на Јовановићем портрету, свечана војна униформа и одликовања са којима је насликан, као и начин на који придржава мач левом руком, веома подсећају на портрете краља Александра Карађорђевића које ће Јовановић сликати за јавне установе у Војводини (Петровић 2012: 155). Репетирање утврђене иконографске структуре било је честа пракса Паје Јовановића, а на овом примеру се додатно потврђује концепт Gelegenheitbilder који је био распрострањен у Угарској пре распада Двојне монархије, а чији се елементи могу препознати и у симболичкој политици Краљевине Југославије. Упадљива разлика између портрета оронулог аустријског цара и југословенског краља у пуној снази говори и о функционисању владарског лика у оквиру државе на заласку и државе која је тек стасавала. Као што је раније био случај са парадним портретима аустроугарског монарха када се владарево трошно тело заодевало у свечану одежду, како би се нагласила вечита снага државе и монархије (БоРОзАн 2014: 166), сада су свечана војничка униформа југословенског краља, испуњена одликовањима, и одлучност његове фацијалне експресије, поред „непропадљивног тела монархије”, истицале и потентност младе „југословенске нације”, као и њен примордијални импулс који је, између осталог, допринео растакању Аустроугарске монархије (IgNjATOVIĆ 2007: 43-72).

Двојни портрет владарског пара намењен новосадској Градској кући поред портрета краља садржао је и портрет краљице Марије Карађорђевић (сл. 2). ${ }^{12}$ У питању је стојећа фигура југословенске краљице представљене у амбијенту који указује на просторије двора, одевена је у хаљину од сатена окер боје. Преко левог рамена јој је

\footnotetext{
${ }^{11}$ Није са сигурношћу утврђено да ли је овај владарски портрет настао као поруџбина или га је Јовановић насликао користећи своје раније настале скице и студије са приказом аустријског цара. Такође се не може поуздано навести коју намену је имао портрет; највероватније да је сликан пре Првог светског рата за потребе смештања у Земаљску банку у Сарајеву.

12 Слика је изведена техником уља на платну, њене димензије износе $152,7 \times 254,5$ cm, њен инвентарни број је ГМС/У 5, а дело је потписано и датирано у доњем десном углу: Паја Јовановић / 1927.
} 
пребачен огртач са крзненом крагном, који придржава десном руком. Краљичина тоалета у потпуности кореспондира са модним трендовима типичним за двадесете године XX века; хаљине равних кројева са изрезима у облику чамца често су допуњаване низовима бисера, баш као што је случај и са портретом краљице Марије. Ипак, будући да је она уживала владарско достојанство, насликана је тако да изнад златне траке коју носи око главе има и раскошну дијадему са смарагдима, коју је израдила кућа Картије (Cartier), француски произвођач луксузног накита и сатова. Као комплет уз дијадему је ишла и огрлица подесиве дужине, те се често могла видети на фотографским портретима краљице Марије; међутим, на овом портрету није у потпуности верно представљена (сл. 5) (MAGAŠ BILANDŽIĆ 2015: 35-36). Овај комплет накита краљица је добила од свог супруга краља Александра Карађорђевића, поводом рођења њиховог сина и престолонаследника Петра II Карађорђевића 1923. године, а креиран је специјално овим поводом. ${ }^{13}$

Још један концепт који је нераскидиви део ношива попут guсмађар хаљине краљице Елизабете јесте концей $\bar{u}$ луксуза $a^{14}$ који ће приликом уобличавања репрезентативне слике југословенске краљице Марије нарочито доћи до изражаја. Ако одбацимо морализаторску перспективу и луксуз прихватимо као незаобилазан у студијама репрезентативне културе, добићемо плодоносне одговоре који се тичу луксуза као оgноcноі йермина (relational term) - оно што је неопходност за једну особу или друштвену групу може бити луксуз за друге. Тако у контексту владарске репрезентације ношиво и орнаменти - било да су у питању владарске инсигније, одликовања, луксузно наоружање или накит у случају жена припадница владарских кућа - јесу комуникациони симболи, означитељи друштвеног поретка и позиције у друштвеној хијерархији (BERRY 1994: 231). Поред тога, моћ луксуза да репрезентује социјални, односно владарски статус, може се посматрати и као механизам помоћу ког се креирају родни идентитети (Mitrović 2008: 197-198). Стога, ако упоредимо хаљину краљице Елизабете у којој је приказана на новосадском портрету, која је истовремено носилац идеолошке одређености, али и луксуза, са хаљином и свим пратећим украсима краљице Марије, увиђамо да је портрет југословенске краљице требало да пошаље другачију поруку од оне коју је еманирала аустроугарска владарка.

Портрет краљице Марије који је извео Паја Јовановић на основу ранијих предложака у свом атељеу у Бечу, приказује је као савремену жену, одевену по последњој моди. Представа жене која ужива у луксузном накиту и исто тако опремљеним дворским одајама, указује на патријархално схватање женског принципа који фигурира

13 Овај Картијеов комплет краљица Марија је поклонила супрузи свог најстаријег сина Петра II - принцези Александри, 1944. године поводом њиховог венчања. Пет година након тога тијара и огрлица су продате, а смарагди су одвојени од остатака огрлице и засебно продати. (https://royal-magazin. de/yugoslavia/emeralds-queen-serbia-necklace.htm).

${ }_{14}$ Концепт луксуза преузет је из BERRY 1994, где је посебна пажња поклоњена одећи и накиту. Аутор настоји да расветли појам луксуза као културолошки условљен антипод ономе што је неойхоgно (necessity). Он луксуз дефинише као последицу људских жеља (desires) и йотиреба (needs). 
у домаћој средини од краја XIX века: „Дужност жене је да чува правила учтивости, финоћу, грациозност" (Домаћииза бр. 10, 1894: 209, наведено према: Mitrović 2008: 199). Портрет је потпуно деидеологизован, ако изузмемо Орден Карађорђеве звезде који означава њену припадност дому Карађорђевића. Упркос томе што је Јовановић у том тренутку припадао старијој генерацији портретиста и што портрет не одудара од идеалистичког реализма типичног за његов опус, портрет краљице Марије одступа од традиционалног владарског портрета и приказује је као жену свог времена, у складу са интернационалним трендовима и гламуром тада све популарнијег Холивуда, што је био случај са Маријиним портретима израђеним у фотографском медију (MAGAš BILANDŽIĆ 2015: 35-36). Присуство Картијеове дијадеме пре упућује на концепт луксуза који дефинише владаркино треће, женско тело, него на владарско достојанство.

Разлог за деидеологизацију слике краљице Марије може се потражити и у политичкој ситуацији композитне Краљевине коју су од самог настанка погађали потреси између народа који су је сачињавали, што ће кулминирати убиством у Скупштини, само годину дана након постављања портрета Карађорђевића у новосадску свечану салу. Осим неколико представа у којима се краљица Марија може видети у српској народној ношњи, за разлику од краљице Елизабете, југословенска владарка није саображавана ниједној етничкој скупини своје државе, већ се стремило приказу краљице као наднационалне фигуре.

Свечана сала Магистрата, односно Градске куће, у Новом Саду функционисала је као јавни простор у ком су се преламали политичко-идеолошки и вредносни системи, пласирани путем сложених сликовних механизама владарске репрезентације. Упркос одсутности двојног портрета Хабзбурговаца, захваљујући делима Ђерђа Ваштага из Ходмезевашархеља, може се у извесној мери реконструисати њихова појавност и упоредити са Јовановићевим ликовним решењем портрета Карађорђевића. И један и други двојни владарски портрет су инсценираном величајношћу династичке слике настојали да надограде крхкост државних структура које су репрезентовали. Портрети Фрање Јосифа и Елизабете Аустријске су показатељ свих компликованих односа у Монархији с краја XIX и почетка XX века када се династичка лојалност, мађарска национална идеја и регионални идентитети преплићу у визуелној култури, са тежњом да их надвладају. Распад Аустроугарске монархије 1918. године поништиће напоре репрезентативних портрета у остварењу циљева политичко-симболичке реалности. Краљевина Срба, Хрвата и Словенаца је осим знатног дела територије Аустроугарске наследила и неке од њених проблема, попут међуетничких тензија, вишеслојне неуједначености у погледу развијености регија и становништва, самим тим и потребу да се владарска фигура наметне као кохезиони фактор разједињене државе. Уклањање владарских слика из јавног простора новосадске Градске куће након смене оба режима, што се може сагледати као „ритуал револуције”, сведочи о 
страху од њиховог делотворног потенцијала који се налази у сржи владарске слике која емитује владарску харизму.

\section{ЛИТЕРАТУРА}

AZARYAhU, Maoz. "Street Names and Political Identity: The Case of East Berlin." Journal of Contemporary History Vol. 21, No. 4 (1986): 581-604.

Аноним. „Новосадска општина објашњава загонетни нестанак слике царице Јелисавете са тавана градске куће.” Време (ANONIM. „Novosadska opština objašnjava zagonetni nestanak slike carice Jelisavete sa tavana gradske kuće.” Vreme (16. X 1936): 9.

БЕшлин, Бранко. „Историја Новог Сада.” У: КАдијевИЋ, Александар (ур.). Уметиничка йоӣoīpaфuja Нової Саgа. Нови Сад: Матица српска (BEŠLIN, Branko. „Istorija Novog Sada.” U: KADIJEVIĆ, Aleksandar (ur.). Umetnička topografija Novog Sada. Novi Sad: Matica srpska), 2014, 62-98.

BERRY, Christopher J. The Idea of Luxury: A Conceptual and Historical Investigation. Cambridge: Cambridge University Press, 1994.

BICSKEI, Éva. “A nemzeti pantheon formálódása. Közgyülési termek arcképcsarnokai a 19. századi Magyarországon.” In: BALOGH, Margit (ed.). Diszciplinák határain innen és túl. Budapest: Fiatal Kutatók Fóruma, 2007, 163-204.

БоРОЗАН, Игор. „Између самоинсценације и презентације: портрет краљице Наталије Обреновић.” Зборник Матиице срйске за тиковне уметиностии (BOROZAN, Igor. „Između samoinscenacije i prezentacije: portret kraljice Natalije Obrenović." Zbornik Matice srpske za likovne umetnosti) 39 (2011): 75-144.

БорОзАН, Игор. Слика и моћ: ирреgстиава влаgара у срйској визуелној кулӣури 19. и йочетиком 20. века (докторска дисертација). Београд: Филозофски факултет (BOROZAN, Igor. Slika i moć: predstava vladara u srpskoj vizuelnoj kulturi 19. i početkom 20. veka (doktorska disertacija). Beograd: Filozofski fakultet), 2013.

БорОзАН, Игор. Сйоменик у храму: Метогіа краља Милана Обреновића у Ћурлини. Београд: Филозофски факултет Универзитета у Београду (BOROZAN, Igor. Spomenik u hramu: Memoria kralja Milana Obrenovića u Ćurlini. Beograd: Filozofski fakultet Univerziteta u Beogradu), 2014.

ВАСИћ, Чедомир. Службено оgело у Србији у 19. и 2о. веку. Београд: Историјски музеј Србије, Галерија САHУ (VASIĆ, Čedomir. Službeno odelo u Srbiji u 19. i 2o. veku. Beograd: Istorijski muzej Srbije, Galerija SANU), 2001.

Vogel, Juliane. “The Double Skin: Imperial fashion in the Nineteenth Century.” In: SCHUlte, Regina (ed.). The Body of the Queen: Gender and Rule in the Courtly World 1500-200o. New York: Berghahn Books, 2006, 216-237.

KovaČEv Ninkov, Olga. Azidöarcai: a szabadkai Városi Múzeum müvészetiosztályánakarcképei Lica vremena: portreti iz zbirke Gradskog muzeja Subotica. Subotica, 2013.

КрчмАР, Филип. Торонйалска жуйанија и юено наслеђе. Зрењанин: Историјски архив (КRС̆MAR, Filip. Torontalska županija i njeno nasleđe. Zrenjanin: Istorijski arhiv), 2016. 
КуцоР, Тамара. „Репрезентација династије и нације: портрет краљице Марије Терезије Мора

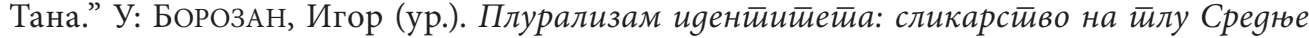
Евройе у йослеgним gеценијама 19. и иочейком 20. века. Београд: Филозофски факултет, Универзитет у Београду (KuCOR, Tamara. „Reprezentacija dinastije i nacije: portret kraliice Marije Terezije Mora Tana.” U: BOROZAN, Igor (ur.). Pluralizam identiteta: slikarstvo na tlu Srednje Evrope u poslednjim decenijama 19. i početkom 2o. veka. Beograd: Filozofski fakultet, Univerzitet u Beogradu), 2020, 81-93.

ЛАзић, Љиљана. „Афера нестанка портрета царице Јелисавете из Градске куће у Новом Саду у светлу новинских извештаја 1936-1938. године." Pag музеја Bојвоgине (LAZIĆ, Ljiljana. „Afera nestanka portreta carice Jelisavete iz Gradske kuće u Novom Sadu u svetlu novinskih izveštaja 1936-1938. godine." Rad muzeja Vojvodine) 58 (2016): 133-148.

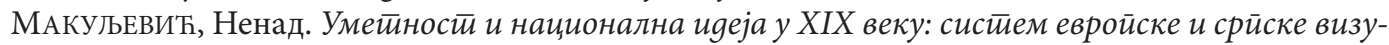
елне кулитуре у служби наиије. Београд: Завод за уџбенике (MAKULJEVIĆ, Nenad. Umetnost i nacionalna ideja u XIX veku: sistem evropske i srpske vizuelne kulture u službi nacije. Beograd: Zavod za udžbenike), 2006.

МиловАновић, Јована. „Визуелизација Миленијумске прославе у Будимпешти 1896. године: слика Дебиле банайских сйахија йреg иарем Фрағьом Јосифом I Пала Вага.” Зборник Нарояноі музеја (MilovANović, Jovana. „Vizuelizacija Milenijumske proslave u Budimpešti 1896. godine: slika Defile banatskih spahija pred carem Franjom Josifom I Pala Vaga." Zbornik Narodnog muzeja) XXII/2 (2016): 201-219.

МиловАновић, Јована. „Национализација владарске слике: портрет царице Елизабете

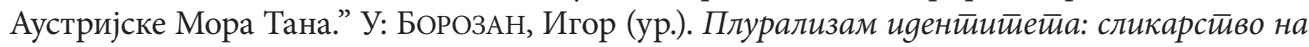
йлу Среgюе Евройе у йослеgюим деценијамаа 19. и йочейком 2о. века. Београд: Филозофски факултет, Универзитет у Београду (MiLOVANOVIĆ, Jovana. „Nacionalizacija vladarske slike: portret carice Elizabete Austrijske Mora Tana." U: BOROZAN, Igor (ur.). Pluralizam identiteta: slikarstvo na tlu Srednje Evrope u poslednjim decenijamaa 19. i početkom 2o. veka. Beograd: Filozofski fakultet, Univerzitet u Beogradu), 2020, 55-79.

Милошевић, Емица, Милена Врбашки. Карађорђевићи у збиркама Галерије Маииице срйске. Нови Сад: Галерија Матице српске (MilošEvić, Emica, Milena Vrbaški. Karađorđevići u zbirkama Galerije Matice srpske. Novi Sad: Galerija Matice srpske), 2004.

Mitrović, Katarina. „Politika roda: luksuz i vizuelna kultura u Srbiji XIX veka.” U: Rosić, Tatjana (ur.). Teorije i politike roda: rodni identiteti u književnostima jugoistočne Evrope. Beograd: Institut za književnost i umetnost, 2008, 195-206.

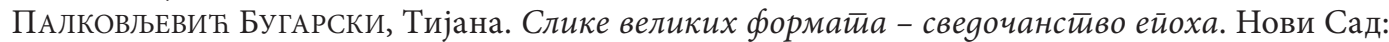
Галерија Матице српске (PALKOVLJEVIĆ BUGARSKI, Tijana. Slike velikih formata - svedočanstvo epoha. Novi Sad: Galerija Matice srpske), 2018.

Петровић, Петар. Паја Јовановић. Систиемайски кайалої gела. Београд: Народни музеј у Београду (Petrović, Petar. Paja Jovanović. Sistematski katalog dela. Beograd: Narodni muzej u Beogradu), 2012.

РАдовић, Срђан. „Идентитети и памћење у јавном простору: одономастика Новог Сада од аустро-угарског до југословенског града.” У: САМАРџИЋ, Момир. Кулииура сећаюа на војвођанском йростоиор. Нови Сад: Филозофски факултет (RAdOVIĆ, Srđan. „Identiteti i pamćenje u javnom prostoru: odonomastika Novog Sada od austro-ugarskog do jugoslovenskog grada." U: SAMARDŽIĆ, Momir. Kultura sećanja na vojvođanskom prostoru. Novi Sad: Filozofski fakultet), 2017, 201-220. 
Szvoboda DomÁnsZKY, Gabriella. “A reprezentatív portré.” In: SisA, Jozef (ed.). A magyar müvészet a 19. században: képzömüvészet. Budapest, 2018, 567-574.

Sidó, Zsuzsa. “The 'Dísmagyar' as Representation in the Andrassy Family in Late Nineteenth Century Budapest." In: SimONTON, Deborah, Marjo Kaartinen (eds.). Luxury and Gender in European Towns, 1700-1914. New York, 2015, 206-223.

SMIT, Antoni. Nacionalni identitet. Beograd: XX vek, 2010.

СтАнчИЋ, Донка, Мишко Лазовић. Новосаgски Маїистирай. Нови Сад: Прометеј (STANČÍ́, Donka, Miško Lazović. Novosadski Magistrat. Novi Sad: Prometej), 2015.

СтАнчић, Донка. Нови Cag og куће go куће. Нови Сад: Студио Бечкерек (STANČÍ́, Donka. Novi Sad od kuće do kuće. Novi Sad: Studio Bečkerek), 2017.

TeLESKO, Werner. Kulturraum Österreich. Die Identität der Regionen in der bildenden Kunst des 19. Jahrhunderts. Wien: Böhlau Verlag, 2008.

Telesko, Werner. Das 19. Jahrhundert, Eine Epoche und ihre Medien. Wien: Böhlau Verlag, 2008. ТимотијевИЋ, Мирослав. Паја Јовановић / Paul Joanowitch. Београд: Народни музеј у Београду (TiмотіJević, Miroslav. Paja Jovanović / Paul Joanowitch. Beograd: Narodni muzej u Beogradu), 2009.

FLECKNER, Uwe, Martin Warnke, Hendrik Ziegler. Handbuch der Politischen Ikonographie I-II. Müncehen: Verlag Beck, 2011.

FleCKNer, Uwe. “Damnatio memoriae.” In: FleCKNer, Uwe, Martin Warnke, Hendrik Ziegler. Handbuch der Politischen Ikonographie I-II. Müncehen: Verlag Beck, 2011, 208-215.

YonAN, Michael. "Interdisciplinary Material Culture Studies and the Problem of Habsburg-Lorraine Representation.” In: TELESKO, Werner (Hg.). Representing the Habsburg-Lorraine Dynasty in Music, Visual Media and Architecture 1618-1918. Wien Köln Weimer: Böhlau Verlag, 2017, 21-37.

Jovana D. Milovanović

CEREMONIAL CHAMBER OF NOVI SAD CITY HALL AS A SPACE FOR THE REPRESENTATION OF RULERS - FROM EMPEROR FRANZ JOSEPH I AND EMPRESS ELISABETH TO KING ALEKSANDAR AND QUEEN MARIA KARAĐORĐEVIĆ

\section{Summary}

The portraits of two ruling couples of the Austro-Hungarian Monarchy and the Kingdom of Serbs, Croats, and Slovenes placed in the Ceremonial Chamber of Novi Sad City Hall shared the same destiny - with the state disappearing, they also disappeared from public representational space. Paintings of the rulers, which were initially placed in the mentioned City Hall - the portraits of Emperor Franz Joseph I and Empress Elisabeth of Austria, were lost without a trace. Very little is known about the Emperor's portrait, being the work of an unknown painter. Hungarian painter György Vastagh made the original portrait of the Empress, known today only via newspaper illustrations. Nevertheless, thanks to the preservation of other dynastic portraits of the same painter from Hungarian town Hódmezővásárhely, which were painted the same year as the painting of the Empress from Novi Sad, there is a possibility to reconstruct their appearance. The fall of the Dual 
Monarchy and the birth of the Kingdom of Yugoslavia resulted in putting the portraits of King Aleksandar and Queen Maria Karađorđević in the same place, even in the same frames. The intention was to embody new ideological aspirations and make the young Kingdom of SCS present in symbolic politics in the newly conquered territory. The famous Serbian painter Paja Jovanović made these portraits of the Karađorđević ruling couple in 1927. Unlike the portraits of Austro-Hungarian rulers, these two are housed in the Matica Srpska Gallery in Novi Sad. The practice known as damnatio memoriae, referring to ruination or total removal of monuments, busts, or paintings from public spaces due to political reasons, resulted from the shift of state regimes throughout the entire history of civilizations. The mentioned portraits of the Habsburg and Karađorđević dynasties were removed precisely as the "ritual act of revolution". The primary purpose of official rulers' portraits in states such as Austria-Hungary and the Kingdom of SCS was to act as a cohesive factor in overcoming real political issues and create a specific political-symbolic reality. After all, both of these two state structures were destroyed. As a consequence, official dynastic portraits of their ruling couples were removed from public space which could be regarded, on the one hand, as an indicator of the fragility of dynastic images in firmly stratified states, or on the other, as an alarming sign of their powerful potential which was an inseparable part of rulers' image radiating ruling charisma.

Keywords: representation of rulers, City Hall in Novi Sad, Austro-Hungarian Monarchy, Kingdom of Serbs, Croats, and Slovenes, Emperor Franz Joseph I, Empress Elizabeth of Austria, King Aleksandar Karađorđević, Queen Maria Karađorđević. 